\title{
Performing Ornaments in English Harpsichord Music. Part I
}

\author{
A. A. Panov $^{1}$, I. V. Rosanoff ${ }^{1,2}$ \\ ${ }^{1}$ St. Petersburg State University, \\ 7-9, Universitetskaya nab., St. Petersburg, 199034, Russian Federation \\ ${ }^{2}$ The Rimsky-Korsakov St. Petersburg State Conservatory, \\ 3, Teatralnaya pl., St. Petersburg, 190068, Russian Federation
}

For citation: Panov, Alexey, and Ivan Rosanoff. "Performing Ornaments in English Harpsichord Music. Part I”. Vestnik of Saint Petersburg University. Arts 11, no. 3 (2021): 381-392.

https://doi.org/10.21638/spbu15.2021.302

The article deals with the problems of interpreting English ornaments (embellishments, graces) of the second half of the $17^{\text {th }}$ century in the process of their evolution. The authors consistently analyze the recommendations of the early English musicians Edward Bevin, Christopher Simpson, Matthew Locke, John Playford, and Henry Purcell. Emphasis in this study is allotted to the first ever published in England full table of ornaments with their execution written by Christopher Simpson in his The Division-Violist (London, 1659). Detailed consideration here is given to the ornament named "Shaked Beat". It should be noted that the first full table "Marques des Agréments et leur signification" in France was enclosed only in D'Anglebert's Pièces de Clavecin (c1689). For comparison, recommendations of the performance of ornaments are provided by some Italian, German and French composers and theorists of this time, such as Emilio del Cavalieri, Guillaume-Gabriel Nivers, Jean Rousseau, Gilles Jullien, Étienne Loulié and Johann Gottfried Walther. A critical revision of scholarly publications on the problems of this study beginning from Edward Dannreuther and Arnold Dolmetsch to the present time has been carried out. Serious inaccuracies were found in the works of modern researchers and in reference and encyclopedic publications, including The New Grove Dictionary of Music and Musicians and Die Musik in Geschichte und Gegenwart.

Keywords: English ornaments, Edward Bevin, Christopher Simpson, Matthew Locke, John Playford, Henry Purcell.

In the article "Performing Ornaments in English Virginal and Harpsichord Music" [1], our attention was focused on two main phenomena of English embellishments during the virginal period. There were many European publications where keyboard music had been abundantly presented in manuscript and later in print. But unlike other countries, English virginal music was so impressively ornamented with special signs during the years of Queen Elizabeth and further on, that solely this fact raises fundamental questions by itself. It is also amazing that having a great many English virginalists, harpsichordists, clavichordists and performers on spinet or manicord (monacord, monocord, monycord, etc.), there was just one musician who left some scarce information on the manner of interpreting ornamentation signs according to his own view, or presumably purely hypothetically - also perhaps according to the views of his colleagues.

(C) St. Petersburg State University, 2021 
As was shown earlier, this musician was Edward Bevin ${ }^{1}$. In the article "Performing Ornaments in English Virginal and Harpsichord Music" [1, p. 55], it was mentioned that no copy of the original MS documents of Add. 31403 with Bevin's "Graces in play" had been at our disposal. Many of the available versions discussing material from Bevin's notes, contained discrepancies concerning the metric measures found in Bevin's example, and could not help to solve the problem.

The copy of the authentic example from "Add. MS 31403" (London British Library) which we came across lately was published by David Hunter in his research in 2002 [4] and later presented in a clearer copy by David Schulenberg [5, Ex. 6].

A comparison of this original version with the note example printed in Arnold Dolmetsch's research showed that the latter had not erred. We are referring to the placement of bar-lines in Bevin's source, because the primary part of Bevin's example was structured metrically consisting of three bars (two minims in the first two bars and a semibreve in the last $\left.\operatorname{bar}^{2}\right)$ :

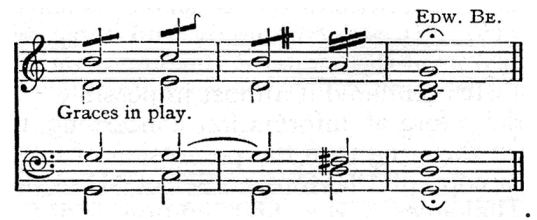

Contrary the part with the "The graces, before, is here exprest in notes", as Bevin writes, is realized in a different metric algorithm:
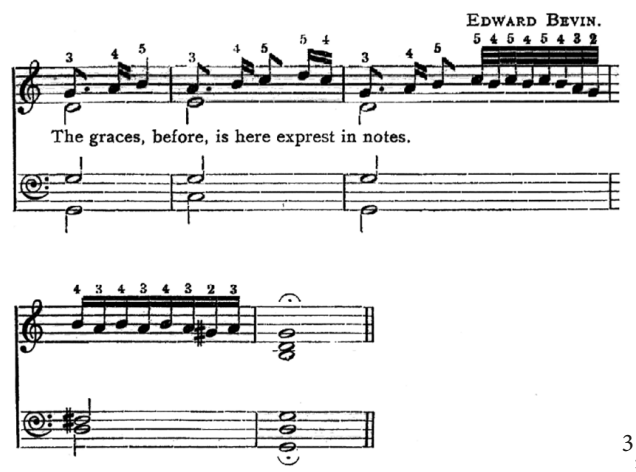

3 , where four bars are represented by minims in each, and the last bar - by a semibreve! One can hardly believe that this last division into bars could belong to Bevin - a professional musician, because it is obviously erroneous. In the previous footnote we speculated that the bar-lines might have been written by someone else or perhaps with a special pedagogical purpose during study.

In Schulenberg's research [5, Ex. 6], the metrical solution is given in full accordance with the musical-theoretical rules of the virginal era, exactly as was previously reasonably shown in our article [1], and recommended still much earlier by Adolf Beyschlag [7, p. 52]:

${ }^{1}$ Edward Bevin (born c1595), son of Elway Bevin. In "Add. 31403" (p. 5), it is clearly written "Edward Bevin" (see: [2, p. 90]). No data is available. The main information concerns the well-known composer and author of an instruction book - Elway Bevin (1554-1638). See also: [3, p.38].

${ }^{2}$ It may be noted that all the bar-lines in the original were written quite clumsily and not with a steady hand. While the note-material seems to be written somewhat more accurate.

${ }^{3}$ Both examples, like in the previous part of our work, are copied from Dolmetsch's monograph [6, p. 387-8]. 


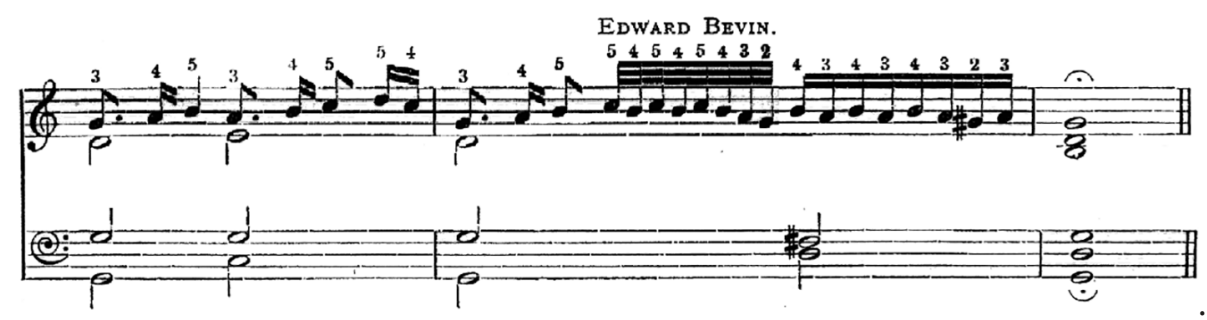

Practically the same interpretation is given in Christopher Simpson's Table under the term of a diminutely compound embellishment named "Double Relish" [8, p. 10; 9, p.12]. For comparison we shall take only the coinciding part of the realization, leaving

out the two appoggiaturas from below (in Simpson's terms — "beats"):

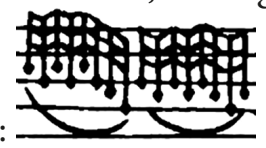
However, there is a slight difference in the rhythm of the two realizations: the second trill is recorded in Bevin's notes in sixteenth durations.

Everything is unique in Bevin's treatment of performing graces because there were no predecessors in the field of keyboard embellishment theory and practice. He had to invent some signs which (as in shorthand - words) would indicate the use of a certain musical note/pattern (grace, ornament, or diminution), so that it could become clear to other performers. It is confusing why Bevin did not try to suggest names for his grace-signs.

Consequently, from the point of view of the subsequent generations of musicians who already have used fairly well-established signs of ornaments, the signs and their resolvation by Bevin may seem strange to say the least. But if it had not been for Bevin's attempt to specify certain ornamental designs with special (stenographic) signs, subsequent musicians would not have had the slightest idea what such signs, found in the works of the Virginalists, could mean. And as was often the case, (without the knowledge of Bevin's "Graces in play") the performers had to make use of principles taken from another (future) stylistic era, in particular, the era of Henry Purcell.

Lastly, to the idiosyncratic manner of Bevin's writing of the signs. Especially one of them seems notably illogical. It is the sign of the compound ornament performed as a shake beginning from the upper auxiliary note and having a cadential turn in the end

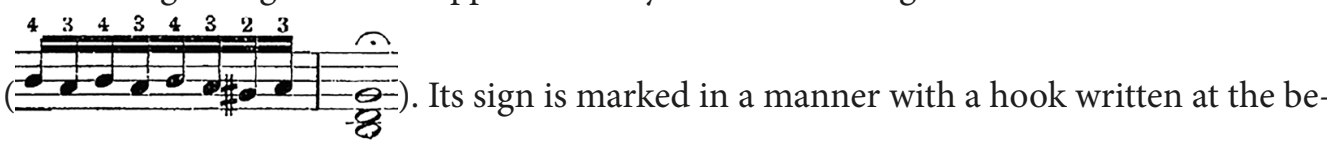
ginning of the parallel slanted dashes. In comparison, the sign of the first ornament sign (n) from the "Graces in play" - the small hook is placed in the end the stroke, and had been used to show that the grace, reminding one of a slide, should be performed with a specific ending using an upper additional note before the next main one In accordance with this logic, the small hook in the previous double-stroked sign of the compound ornament should also be written at the end to show that this ornament could be performed with a cadential ending turn as well, but, strangely, the small hook is written 
in the beginning of the sign. Robert Donington [10, p. 732] calls this sign and its execution "Trill with turned ending". If $a$ priori (in principle) we assume that a cadential shake which begins from the upper auxiliary note in those times should have ended with a cadential turn, then, as a hypothesis, we may suggest that this hook - printed by Bevin in the beginning of the parallel double strokes - could have shown an embellishment (shake) beginning from the upper auxiliary note with a "turned ending" (Donington). Otherwise, there is nothing in the notes which might be interpreted as extraordinary. Or we must accept Bevin's controversial character of this sign. Previously somehow the placement of this small hook did not attract the attention of scholars. Perhaps another solution could be presented!

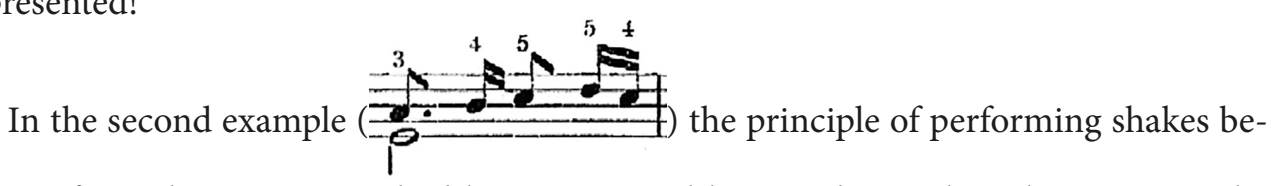
ginning from the upper note had been presented by two diagonal strokes crossing the main oblique line (-\#). In this example, it is clearly shown that these two strokes are to be interpreted as a shake from the upper auxiliary note with a tirata-pattern-ending (or any other pattern).

Asako Hirabayashi argued that "his [Bevin's] use of ornament signs was inconsistent and idiosyncratic to the extent that his table should not be accepted as accurately reflecting general practice in the virginalist era" $[11, \text { p. 93 }]^{4}$. The second part of Hirabayashi's argument requires no commentary. But hardly should Bevin's "Graces in play" together with "The graces, before, is here exprest in notes" be characterized as "inconsistent", because the oblique line in the example definitely is interpreted as a slide-like ornament

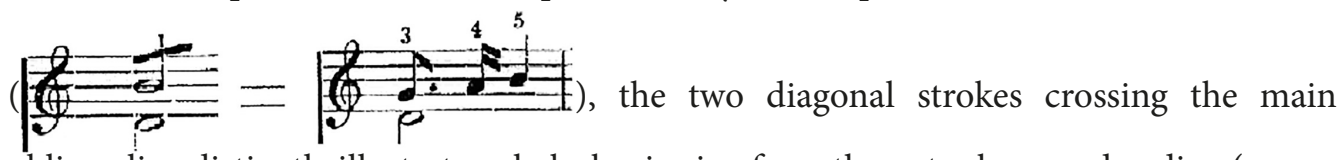
oblique line distinctly illustrate a shake beginning from the note above and ending (as was the custom/cliché in those days) with a downward tirata or other diminution.

It should always be kept in mind that from the point of view of musicians of the future generations, especially after almost four hundred years, Bevin's first attempt to create something new without having any previous keyboard examples could certainly not be ideal. It is also clear that in the dynamically developing musical period of the subsequent quarters of the $17^{\text {th }}$ century, not all the invented signs of ornamentation continued to be used. One should take into account the fact that many composers of different national schools of the $16^{\text {th }}-17^{\text {th }}$ centuries (and later on) created their own "tables" deciphering ornaments. In these cases, certain signs of embellishments and their deciphering could coincide with some previous ones, and others - not, especially if we take into account the rapidly changing stylistic trends. Bevin was the first person in England to undertake such an experiment.

A similar critical approach, for example, could be addressed to the author of the first small Table with the execution of ornaments in Italy compiled by Emilio Cavalieri, and

${ }^{4}$ Earlier, the same topic was discussed in the work of Eiji Hashimoto. It says: "<...> however, they [the essential graces] too create confusion and ambiguity, because the ornamental signs were used in such diverse and inconsistent ways, often under different names, that discrepancies and contradictions are bound to occur." [12, p.7]. 


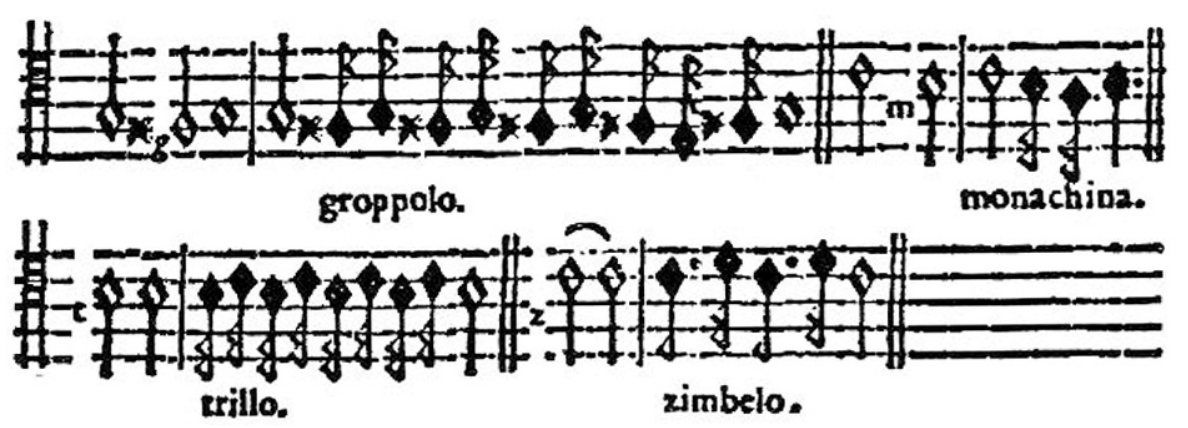

Example 1. Emilio del Cavalieri, "Rappresentatione di Anima <...>" [13, p. 3]

published in 1600 [13, p. 3] (see Ex. 1). Here, from our point of view, the name "zimbelo" and its sign ("z") are inappropriate, but the composer had the right and wanted to name this ornament in such a manner. Many similar examples can be easily uncovered in the music of other composers.

The evolutionary process progressed in its own way, and in the quite nearest future new rules and new signs of graces began to be used by English musicians. However, for approximately more than sixty years until the publication of Purcell's A Choice collection of Lessons in 1696 [14] no explanations for performing English keyboard embellishments had been yet found in print, or in MS.

Melothesia by Matthew Locke published for the harpsichord or organ was an exception, but in this edition only a row of ornament names and their signs is provided (see Ex. 2). Not a word is said about the manner of realizing these most significant embellishment signs in notes. Most authors studying ornamentation refer to Willi Apel's reputable solution, and for this reason along with Locke's text we show Apel's resolvations.

However, before Locke's Melothesia an extremely important English ornamentation scholarly source was published in The Division-Violist by Christopher Simpson (Sympson) in 1659 [8]. There existed no great difference in instrumental and keyboard ornamentation in the middle of the $17^{\text {th }}$ century music performance in England. The further the music evolved, the less (and sometimes - the more) the differences became. By the turn of the third quarter of the $17^{\text {th }}$ century especially when John Casper Heck published his instructive manual containing general information about C.P.E. Bach's Verzierungen [17], the differences were becoming more apparent. One should generally take into account the growing French influence especially following the publication of Six Suittes composed for Madama la Comtesse de Sandwich by Charles Dieupart in the beginning of the $18^{\text {th }}$ century accompanied by an Explication des Marques [18, p. 49].

The middle of the $17^{\text {th }}$ century is definitely distinguished by Simpson's publication of his treatise and tutor (in one book). It is an outstanding work designed for study and perfection in "ex tempore Modulandi Ratio" ("The Art of Playing Ex tempore upon a Ground") - many publications on the practice of diminution, perhaps beginning from the copious treatise by Diego Ortiz for "Violone" [19], were written for different instruments during more than three hundred years. But Simpson was the first to include in his work a detailed table with the deciphering of the thirteen ornaments (see Ex. 3).

In France, the first small Table with the execution of ornaments was included in the Collection of Pieces for harpsichord by Jacques Champion de Chambonnières only in 
Matthew Locke

"Melothesia"

a Foriefall.

$\backslash$ a Back-fall.

a shake.

- a Fore-fall and shake:

u a Beat.
Willi Apel

"The History of Keqboard

Music" (p. 751)

Example 2. Matthew Locke, "Melothesia" [15, p. 5]; Willy Apel, "The History of Keyboard Music" $[16, \text { p. } 751 \text {, Fig. } 837]^{5}$

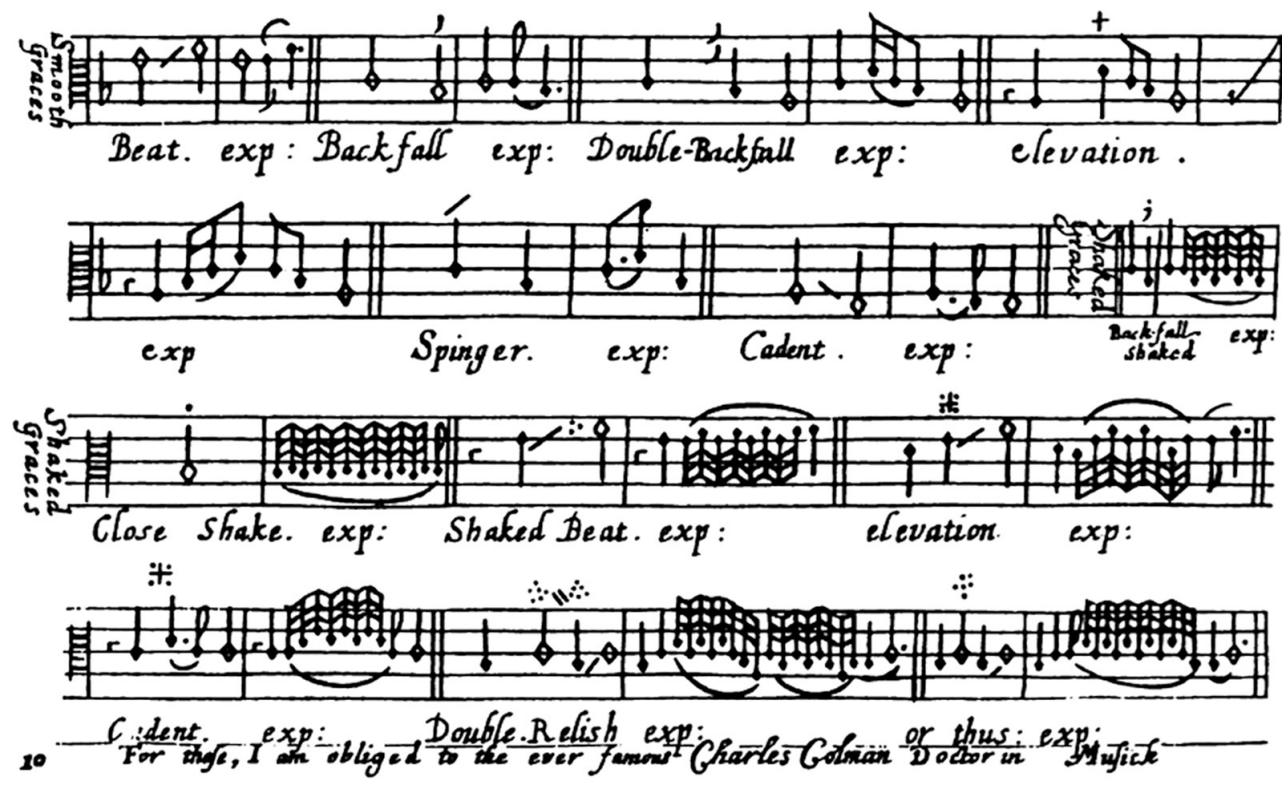

Example 3. Christopher Simpson, "The Division - Violist" [8, p. 10] ${ }^{6}$

1670 [20]; the first complete set (Table) with the realization of ornaments was published c1689 by the French pupil of Chambonnières Jean Henry d'Anglebert in his remarkable first collection of pieces for the harpsichord [21]. In Germany and Italy scholarly research has not found anything similar to that which could be called a "Table". Three ornaments with their execution included in the edition of organ music by Guillaume-Gabriel Nivers [22] are interesting but fail in comparison with Simpson's which demonstrates an example of

${ }^{5}$ We have slightly changed the order in which Apel presents his Table so that his ornaments would coincide with Locke's. In Apel's order from above in the fourth place comes the "Beat" and next - the "Forefall and shake". We cannot be definitely sure that Apel's resolvation is the only possible one: this item will be touched on later.

${ }^{6}$ In the second bar of the second line there is a term "Spinger". J. Playford and some others wrote "Springer". Playford in his 1660 edition [25, p. 79] calls the ornament "Springer". 
Art including the typing and the thorough, systematic presentation of the material (Ex. 3). Simpson's execution is understandable at first glance, and along with this it has been studied by many scholars. We shall try to concentrate on the most relevant topics below.

We shouldn't leave unnoticed - as has been done before and later too - the handwritten text at the end of the Table which says: "For these, I am obliged to the ever famous Charles Colman [Colemann] Doctor in Musick" (died in 1664). Colman (or Coleman) was an esteemed singer, lutenist, violist. Edward Dannreuther [23, p.X] regards him as (a harpsichord player) [parentheses - Dannreuther's].

A notable fact is that the second edition of Simpson's treatise is bilingual: Latin texts are given parallel or placed above the English ones. The text of the title page had been changed as well: "Chelyes Minuritionum Arttificio Exornata $<\ldots$. " which corresponds to the English lexeme "The Division-viol” [9].

Simpson's Table was thoroughly studied beginning from E. Dannreuther, A. Dolmetsch and later authors of our times. But there are still many important items left to be discussed or disputed. One item is certainly overdue. It has to do with the chronology of dating events under consideration in our work and mentioned previously by scholars. Since the time of the publication of Dolmetsch's monograph, there have been constant inaccuracies in the dating of the matters expressed in the works of Christopher Simpson and John Playford. It was Dolmetsch who began to attribute information from Playford's later works to the first edition of Playford's A Breefe Introduction [24], in which there was no such information. The author states: "From the middle of the $17^{\text {th }}$ century the shake began to establish itself, and a long list of documents containing precise instructions on the subject is available. It begins with Playford's Introduction to the skill of Music, 1654: -

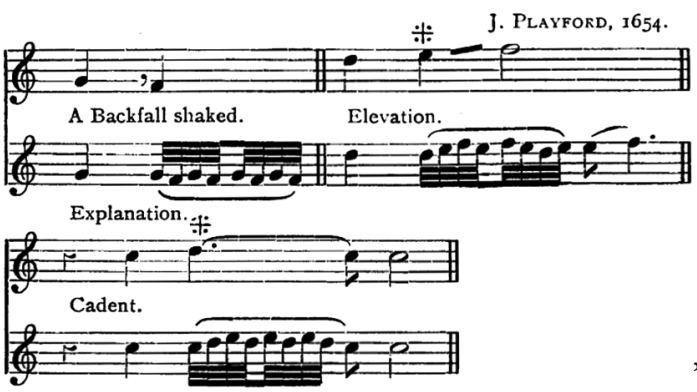

" $[6, \mathrm{p} .160]$. It is necessary to clarify with all certainty that in the first edition of Playford's A Breefe Introduction (1654), there is no Table of graces, and no "precise instructions on the subject". For the first time "A Table of Graces proper to the Viol or Violin" [literally the above shown Simpson's execution of ornaments] was printed in Playford's 1660 edition [25, p. 79]. On pp. 78-79 Playford expresses his obligation to Simpson's "excellent Book" and pays his respect to the "Eminent Charles Colman, Dr. in Music". In the $12^{\text {th }}$ edition "Corrected and amended by Mr. Henry Purcell” [26], the "Table of Graces" is printed on p. 79, but neither Simpson nor Coleman is mentioned.

Not long after, Dieter Gutknecht resumes in the article "Verzierungen" in the MGG2, that for the "first time in the work by J. Playford ( $\left.{ }^{7} 1674\right)$ one finds the Schleifer also [played] from above and marked as 'double backfall', which is shown by two differently placed commas (Häkchen) one above the other after the note <... ${ }^{7}$ [27, col. 1432]. Gutknecht is well

${ }^{7}$ It is not possible to discuss all discrepancies. We selected several to show that the source-material is not only difficult, but is immense in quantity. 
acquainted with Simpson's The Division-Violist. It is unexplainable why Gutknechet used as an illustration in his article "A Table of Graces proper to the Viol or Violin" of 1674 from Playford's "Instruction", but not Simpson's original Table published fifteen years earlier in 1659. Concerning the statement about the "double backfall," there is another error here: we checked Simpson's Table [8, p. 10] with the "Table of Graces proper to the Viol or Violin" $[28$, p. 116] copied from Simpson by Playford, and discovered that (from our opinion) both examples are identical (see Ex. 4$)^{8}$

Gutknecht, 1998, Sp. 1432

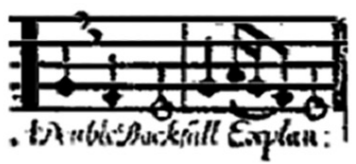

Simpson, 1659 , p. 10

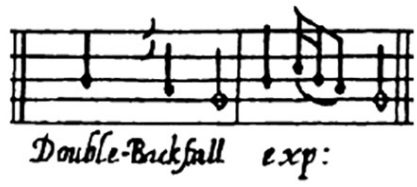

Example 4. Comparison of the execution of the "Double-Backfall" copied by Gutknecht from Playford's 1674 edition and Simpson's original example does not detect any differences ${ }^{9}$

Thus, the first time the "double Back-fall" in ornamentation Tables is given namely in Simpson's work [8, p. 10], but not in Playford's "seventh" edition [28, p. 116] as Gutknecht states. As a matter of fact, this "double Back-fall" - it goes without saying - is also in the Table printed in Playford's “Third” edition [25, p. 79].

Regarding the Graces themselves, it is well known that one of Simpson's important smooth graces was named "Beat" and printed as an oblique line between two notes. It meant a lower appoggiatura and it was performed according to the principle of Subtraktion (Beyschlag). Later Simpson's term "beat", as we previously have noted, was entered in M.Locke's [15] list but written as a smooth wavy (zig-zag) line. There is no direct scholarly evidence that this wavy line might not have meant Simpson's "Shaked beat" which represented a multi-repeated appoggiatura beginning from the lower auxiliary note

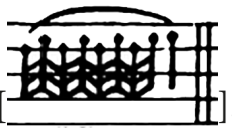

]. Locke hardly could have meant Simpson's "beat" as a lower appoggiatura because he calls the latter a "Fore-fall". Most likely by the wavy line (mu) Locke implied an embellishment played with several reciprocations of the lower and upper notes [this is only our hypothesis]. However, if we take a step forward and search in Henry Purcell's Rules for Graces we will find the same sign (wavy lines) as Locke's (“韭”) and named also as "beat". Its performance by Purcell is next:

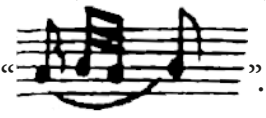

It is most likely that

${ }^{8}$ A similar mistake is made by Kah-Ming Ng in The New Grove Dictionary of Music and Musicians $[29$, p. $718-9]$.

9 Except that Simpson's work was printed much better than Playford's notwithstanding the fact that both works were printed at the same typography - by William Godbid. Simpson and Playford, as we presume, were in good friendly terms, so such things did not matter for them. Secondly, that the Playford used violin notation, since the Table is included in the section on violin art, and Simpson's Table is notated for the viol. 
Apel took advantage of the Purcelean interpretation (the outstanding scholar did exactly the right thing) to make use of it in Locke's situation. In other words, Purcell interprets the sign as a short "lower" mordent. The word "lower" is understood as a performance of an ornament which begins with the lower auxiliary half or whole tone. This transformation of the appoggiatura/beat into a lower mordent as well as the new naming and interpretation will not be difficult to understand. Thus, if we return to Simpson's Table we shall see among the "shacked Graces" a "Shacked Beat". It meant nothing else but a multiple repetition of the ordinary Simpson's "beat" (an appoggiatura from the lower note repeated many times). In Simpson's Table it is accomplished according to the metric length of the notes. Concerning the term itself in everyday practice there was no sense for the musicians to always repeat "shacked beat". The word "shake" had been taken out, and only the term "Beat" was left, but in principle the word "Beat" meant a "shacked beat"!

The story with the "Beat" only begins here. Previously we mentioned the "three" ornaments found in G.-G. Nivers' Livre d'Orgue contenant Cent Pieces de tous Tons de l'Eglise $\langle\ldots\rangle$ [22]. One of the ornaments at its core function represents Simpson's "shaked beat"! There is yet no answer to the question of the origin of Colemann's embellishment table included by Simpson, and what connects the latter's execution with Nivers. Furthermore, Nivers does not give this lower mordent some special name. In Nivers Livre, it is just called "l'Agrément", i.e., "Ornament", "Embellishment". This could only mean that the lower mordent named ("l'Agrément") was so widely spread that there was no need to give it a special name. The three Nivers' ornaments are shown below in Ex. 5.

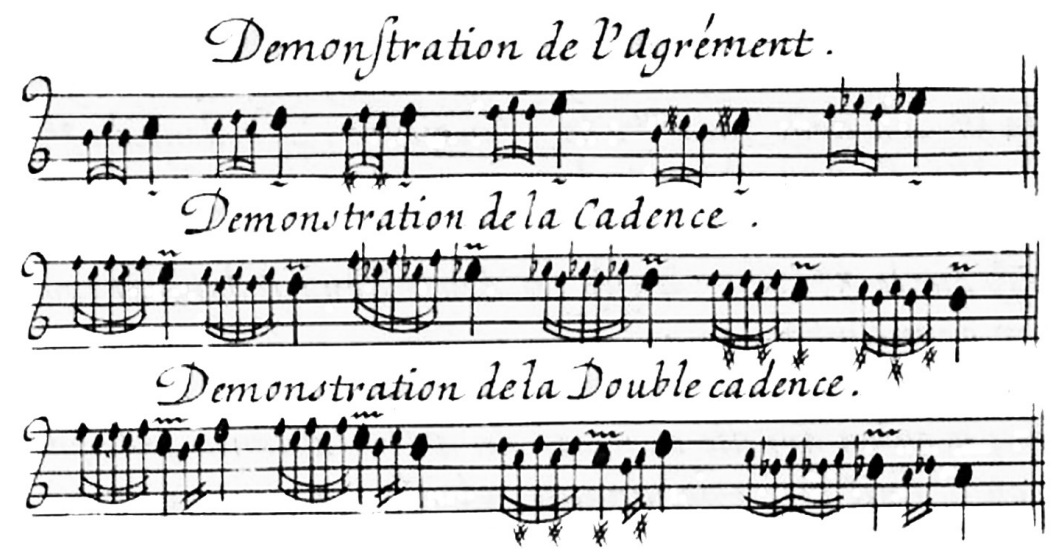

Example 5. G.-G. Nivers, "Livre d'Orgue contenant Cent Pieces de tous Tons de l'Eglise" [22, Preface, s. p.]

The signs of the l'Agréments are written here under the crotchets. French composers of that time wrote the resolvations of the embellishments before the main note. It definitely did not mean that the beginning of the latter should be performed not on the metrical beat, i.e., not together with the main note, but before it.

One might presume that "Demonstration de l'Agrément" is the title of this small Table. In the previous text it is clearly written that "There are three kinds [of "Cadences ou Tremblemens"], named and written as follows: the Agrément, $\sim$, the Cadence $\mathbf{N}$ and the Double cadence $\mathbf{W}$. Examples of them are provided below, $<\ldots>$. 
Let us refer to the material from the treatise of de Saint Lambert who comments on Nivers' Table: "The tremblement [shake] that M. Nivers calls the AGRÉMENT is the same as that which the other masters call the PINCÉ, $\langle\ldots\rangle$, except that it starts on the borrowed note [lower auxiliary note] and the others start it on the main note" [30, p.47].

In 1678 the famous French violist Jean Rousseau (1644-1699), theorist and author of a singing treatise published a Traité de la Viole. The intention in his "Traité" is set out very clearly and precisely, presenting it in an understandable form for every musician: "The martellement [i.e., mordent] is always inseparable from the Port de Voix because the Port de Voix is always concluded by a martellement. It is an agrément which the voice makes naturally by a small shaking of the throat in completing the Port de Voix, this is the reason why instruments must imitate it" [31, p. 87-8]. It is strange that Rousseau does not mention this interpretation in his vocal work written five yers earlier! It is quite obvious that the final clarification reflects the French gout. But in general, Rousseau recommends playing the compound ornament "Martellement" with the "Port de Voix" [according to Christopher Simpson it is "the shaked Beat"] beginning from the lower auxiliary note. Unlike Rousseau, as for the notes of decoration, the explanations of Martellement/mordent in the treatise of Etienne Loulié completely coincide with the interpretations proposed by Chambonnier, d'Angleber, and J.S. Bach. Louliés table with martellements had been printed in the manner adopted in the period of the late $17^{\text {th }}$ - first 30-40 years of the

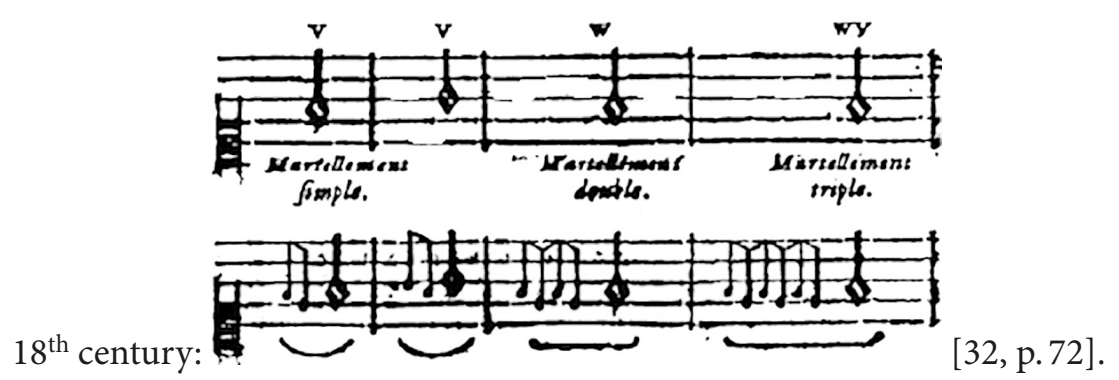

Theoretically and practically the same manner of performing mordents beginning from the lower auxiliary note (as by Simpson and Nivers) is recommended in the Premier livre dorgue by Gilles Jullien which may be seen in a small Table (Ex. 6).

The most interesting in Jullien's marking is that the mordent from below called "Agrément ou pincement" is written as a "usual" French mordent, the sign used from Chambonnières [34]. Lastly it must be especially noted that Johann Gottfried Walther was also under a strong French influence in the field of embellishments. In Walther's monumental MS treatise [35] there is an example showing how mordents must be performed (see Ex. 7). This material is not only interesting but also very important in the history of performance. On p. 89 of the MS ( $\$ 6)$ Walther explains: "With [The signs] ( 4 ) a Mordens or Mordentia is meant; which figure [execution] is much alike the Triller; excepting that the Mordant always uses for its expression a semitone or whole tone from below. For Ex."

Lastly - notwithstanding that it is not exactly proper - after all these materials it is necessary to return to England and justify that in Purcell's Rules for Graces $(1696,1697)$ his "beat" is marked as M. Locke marked it. And the text relating to the "beat" reads:

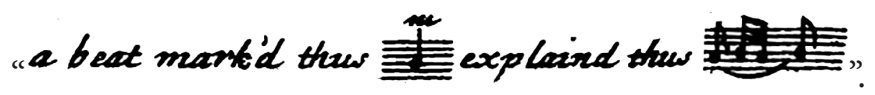




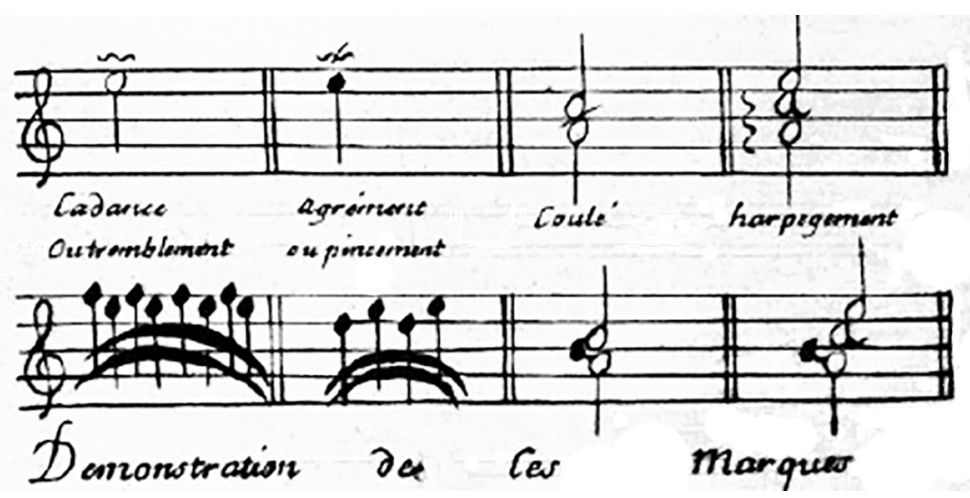

Example 6. Gilles Jullien, "Premier livre d’orgue" [33]
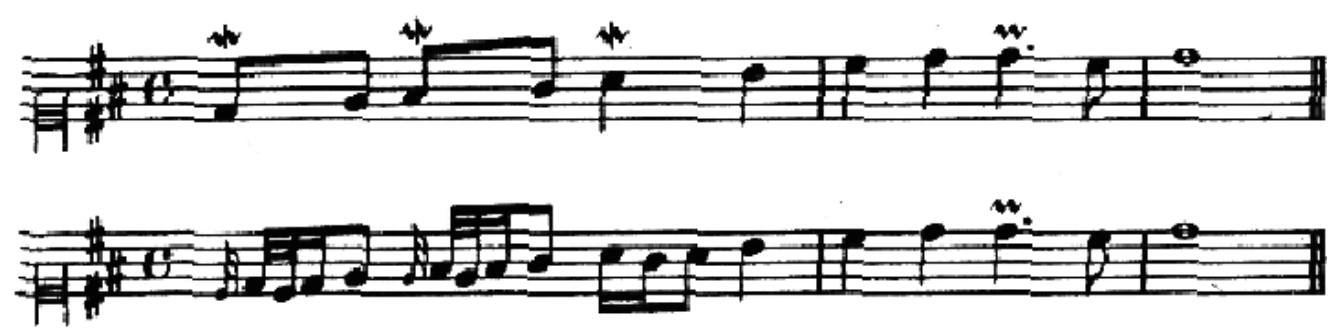

Example 7. Johann Gottfried Walther, "Praæcepta der Musicalischen Composition” [35, p. 89]

Here we turn our attention to Simpson's The Division-Violist only to one ornament, but still a few should be commented upon before we begin the coming research on the embellishments of the Purcellian and post-Purcellian time: "Performing Ornaments in English Harpsichord Music. Part II”.

\section{References}

1. Panov, Alexey, and Ivan Rosanoff. "Performing Ornaments in English Virginal and Harpsichord Music (Based on the Study of Original Interpretation Instructions)." Vestnik of Saint Petersburg University. Arts 10, no. 1 (2020): 41-67. https://doi.org/10.21638/spbu15.2020.103.

2. Hughes-Hughes, Augustus. Catalogue of Manuscript Music in the British Museum <...>. 3 vols. London: Longmans \& Co.; Asher \& Co.; Henry Frowde; Oxford University Press Warehouse, 1909, vol. III: Instrumental Music, Treatises, etc.

3. Caldwell, John. "Sources of Keyboard Music to 1600". In The New Grove Dictionary of Music and Musicians, ed. by Stanley Sadie, vol. 24: 19-39. $2^{\text {nd }}$ ed. London: Macmillan, 2001.

4. Hunter, Desmond. "The Dublin Virginal Manuscript: New Perspectives on Virginalist Ornamentation". Early Music 30, no. 1 (2002): 68-80.

5. Schulenberg, David. "Historical Fingering, Articulation, and Ornamentation in Seventeenth-Century Keyboard Music: Does It Matter? < ..> Musicology Colloquium, Princeton University. March 11, 2019". Accessed November 05, 2020. https://4hlxx40786q1osp7b1b814j8co-wpengine.netdna-ssl. com/david-schulenberg/files/2019/03/Schulenberg_Princeton_talk_11Mar2019_handout.pdf.

6. Dolmetsch, Arnold. The Interpretation of the Music of the Seventeenth and Eighteenth Centuries. Ed. by Ernest Newman. London: Novello and Company, n. d. [1915].

7. Beyschlag, Adolf. Die Ornamentik der Musik <...>. Leipzig: Breitkopf \& Härtel, 1908. (Urtext Klassischer Musikwerke).

8. Simpson, Christopher. The Division-Violist: Or an Introduction to the Playing upon a Ground $\langle\ldots\rangle$. London: Printed by William Godbid, 1659. 
9. Simpson, Christopher. The Division-Viol: or, The Art of Playing Ex tempore upon a Ground. $<\ldots>.2^{\text {nd }}$ ed. London: Printed by W. Godbid for Henry Brome $<\ldots .>, 1665$.

10. Donington, Robert. The Interpretation of Early Music. Rev. ed. New York: W. W. Norton \& Co, 1992.

11. Hirabayashi, Asako. "A New Interpretation of the English Virginalists' Ornament Signs". Early Keyboard Journal 25/26 (2010): 93-123.

12. Hashimoto, Eiji. "Baroque Ornamentation: A Guide to Correct Interpretation". The American Music Teacher 29, no. 2 (1979): 6-10.

13. Cavalieri, Emilio, del. Rappresentatione di Anima, et di Corpo <...>. Roma: Apresso Nicolò Mutij, 1600.

14. Purcell, Henry. A Choice Collection of Lessons for the Harpsichord or Spinnet. London: Printed on Copper-Plates for $\mathrm{M}^{\mathrm{rs}}$ Frances Purcell, executrix of the author $\langle\ldots>, 1696$.

15. Locke, Matthew. Melothesia, or, Certain General Rules for Playing upon a Continued-Bass with a Choice Collection of Lessons for the Harpsichord and Organ of All Sorts: <...>. London: J. Carr, 1673, pt. 1.

16. Apel, Willi. The History of Keyboard Music to 1700. Transl. and rev. by Hans Tischler. Bloomington: Indiana University Press, 1972.

17. Heck, John Casper. The Art of Fingering. Or the Easiest and Surest Method How to Learn to Play on the Harpsichord with Propriety and Expedition, Being Exemplified by Gradation of Fine Lessons $<\ldots . .>$. As also Explanation of all Graces, Shakes, and several marks referring thereto $\langle\ldots\rangle$. The manner of Fingering, as well as the Explanation of Graces, is entirely regulated after the Rules and Method of the Celebrated C. P. E. BACH of Berlin <...>. London: W. Randall \& I. Abell, n. d. [c1766/7?].

18. Dieupart, Charles. Six Suittes de Clavessin Divisées en Ouverture, Allemandes, Courantes, Sarabandes, Gavottes, Menuets, Rondeaux \& Gigues <...>. Amsterdam: Estienne Roger, n. d. [c1701/2].

19. Ortiz, Diego. Trattado de glosas sobre clausulas y otros géneros de puntos en la música de violones nuevamente puestos en luz, <...>. Roma: por Valerio Dorico, y Lúis su hermano, 1553.

20. Chambonnières, Jacques Champion, de. Les Pieces de Claueßin <...>. Paris: Jollain, 1670, liv. 1.

21. D’Anglebert, Jean Henry. Pieces de Clavesin <...>. Paris: l'Autheur, s. d. [c1689].

22. Nivers, Guillaume-Gabriel. Liure d'Orgue Contenant Cent Pièces de tous les Tons de l'Église. <...> Paris: l'Autheur $\langle\ldots\rangle$ et R. Ballard, 1665.

23. Dannreuther, Edward. Musical Ornamentation. Ed. by John Stainer. 2 parts. London; New York: Novello, Ewer and Co., n. d. [c1893/95], pt. 1.

24. Playford, John. A Breefe Introduction to the Skill of Musick for Song \& Violl <...>. London: s. n. [the Author], 1654.

25. Playford, John. A Brief Introduction to the Skill of Musick $<\ldots>$. $3^{\text {rd }}$ ed. London: Printed by W. Godbid for John Playford, 1660.

26. Playford, John. An Introduction to the Skill of Musick. <...> Corrected and amended by Mr. Henry Purcell. $12^{\text {th }}$ ed. [London]: Printed by E. Jones, for Henry Playford, 1694.

27. Gutknecht, Dieter. "Verzierungen”. In Die Musik in Geschichte und Gegenwart: allgemeine Enzyklopädie der Musik, hrsg. von Ludwig Finscher. Sachteil, Bd. 9: 1418-64. 2. Auflage. Kassel u. a.: Bärenreiter, 1998.

28. Playford, John. An Introduction to the Skill of Musick. $<\ldots>.17^{\text {th }}$ ed. London: Printed by W. Godbid for John Playford, 1674.

29. Ng, Kah-Ming. "English Baroque". In Ornaments in The New Grove Dictionary of Music and Musicians, ed. by Stanley Sadie, vol. 8: 717-21. $2^{\text {nd }}$ ed. London: Macmillan, 2001.

30. Saint Lambert, de. Les principes du clavecin, <...>. Paris: Christophe Ballard, 1702.

31. Rousseau, Jean. Traité de la viole, qui content une dissertation curieuse sur son origine. Une démonstration generale de son manche en figures, avec leurs explications $<\ldots$. . Paris: Christophe Ballard, 1687.

32. Loulié, Etienne. Elements ou principes de musique, mis dans un nouvel ordre. tres-clair, tres-facile, \& tres-court, \& divisez en trois Parties <...>. Paris: Christophe Ballard, 1696.

33. Jullien, Gilles. Premier Liure d'Orgue <... >. Paris: Richar, Henry Lesclop, s. d. [c1690/5].

34. Chambonnières, Jacques Champion, de. Les Pieces de Claueßin <...>. Paris: Jollain, s. d. [c1670/90], liv. 2.

35. Walther, Johann Gottfried. Praecepta der musicalischen Composition (MS, 1708), Hrsg. Peter Benary. Leipzig: Breitkopf \& Härtel, 1955. (Jenaer Beiträge zur Musikforschung, 2).

Received: April 29, 2021

Authors' information:

Accepted: May 27, 2021

Alexey A.Panov - Dr. Habil., Professor; a.panov@spbu.ru

Ivan V.Rosanoff - Dr. Habil., Professor; i.rozanov@spbu.ru 